\title{
Research on the Whole Process Cost Risk Evaluation Index System of Real Estate Park
}

\author{
Bing Xu and Qinling Zeng \\ School of Civil Engineering, North China University of Technology, Beijing, China
}

\begin{abstract}
The development focus of real estate enterprises has shifted from traditional buildings to industrial park construction. After summarizing and analyzing the risk factors of the traditional construction cost, the WBS-CBS-RBS method is used to classify and identify the whole process cost of the industrial park. Finally, eight first level evaluation indexes and 37 second level evaluation indexes are established to form the whole process cost risk evaluation index system of the industrial park construction, which provides the basis for the whole process cost risk assessment of the subsequent industrial park construction.
\end{abstract}

\section{Introduction}

The development of China's real estate market has been controlled by national policies and the market supply and demand chain changes. The development of residential and commercial buildings is no longer the development trend of real estate enterprises. The real estate business responds to the call of the country under the policy regulation, the transformation expands the industrial real estate. In the previous studies, the cost risk evaluation index system for the construction unit was established from the perspective of the construction party. It is more difficult for real estate developers to control the cost of the whole process in the construction of industrial parks.

\section{Establishment objectives and contents of the industrial park's cost risk evaluation index system}

\subsection{Target objects of the indicator system}

In the traditional sense, a park is planned by the government in a unified way. A certain type of specific industry is set up within the region and specific enterprises are introduced for unified management. Typical parks include industrial parks, theme parks, industrial parks, agricultural parks, etc. In this paper, the high-tech industrial park in the transformation type of real estate enterprises is selected as the research object. China's high-tech industrial parks enjoy many preferential policies, by the state to support, is the construction and development of high-tech industrial base.

\subsection{Target content of the indicator system}

The whole process construction of industrial park is a complex system engineering, which involves a wide range of specialties. From the perspective of real estate enterprises, including the three stages of planning, construction and operation, the control of whole-process cost is the work throughout the entire construction cycle. For industrial parks, cost control mainly covers the cost expenditure within the construction cycle and the income in the later stage of operation. Sustainable development of industrial parks mainly depends on reasonable control of the whole process of construction. From the planning and design of industrial parks to the construction and construction, and then to the operation and maintenance of industrial parks, it is necessary to establish a complete set of cost risk evaluation index system to control the construction cost of industrial parks, so as to provide a foundation for sustainable development of industrial parks.

\section{Cost risk factor identification based on WBS-CBS-RBS}

\subsection{WBS work breakdown structure}

According to the characteristics of the whole construction process of the industrial park, the whole construction process is divided into three stages: project planning, construction implementation, operation and maintenance. The concrete decomposition structure is as follows (Figure. 1).

\footnotetext{
* Corresponding author: 19801289803@163.com
} 


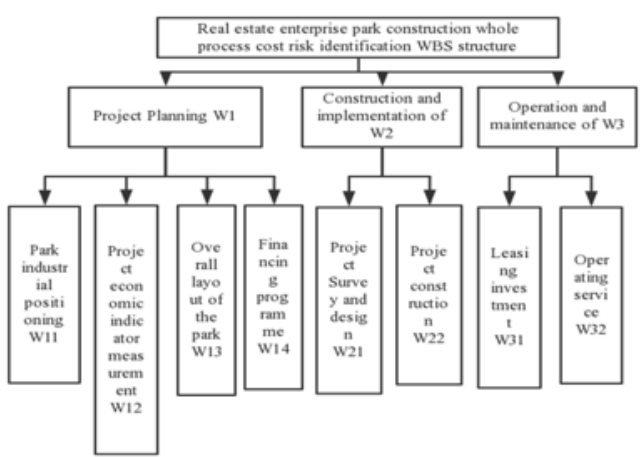

Figure 1. Risk identification WBS structure

\subsection{CBS cost breakdown structure}

The costs of different stages in the whole process of industrial park construction are different. The specific costs are as follows (Table 1) :

Table 1: Cost composition of the whole process of park construction

\begin{tabular}{|c|c|c|}
\hline \multicolumn{3}{|c|}{ - } \\
\hline $\begin{array}{c}\text { Construc } \\
\text { tion } \\
\text { phase }\end{array}$ & Work structure & Cost composition \\
\hline \multirow{5}{*}{$\begin{array}{c}\text { Project } \\
\text { planning }\end{array}$} & \multirow{2}{*}{$\begin{array}{l}\text { Park industrial } \\
\text { positioning }\end{array}$} & Municipal research fee \\
\hline & & Peripheral investigation fee \\
\hline & $\begin{array}{c}\text { Project economic } \\
\text { evaluation }\end{array}$ & Feasibility study cost \\
\hline & $\begin{array}{c}\text { Overall layout of } \\
\text { the Park }\end{array}$ & Planning cost \\
\hline & Financing & Financing cost \\
\hline \multirow{10}{*}{$\begin{array}{l}\text { Construc } \\
\text { tion of } \\
\text { the } \\
\text { impleme } \\
\text { ntation }\end{array}$} & \multirow{3}{*}{$\begin{array}{l}\text { Project Survey } \\
\text { and design }\end{array}$} & $\begin{array}{l}\text { Land cost } \\
\end{array}$ \\
\hline & & $\begin{array}{c}\text { Preliminary cost of engineering } \\
\text { survey and design }\end{array}$ \\
\hline & & The bidding fee \\
\hline & \multirow{7}{*}{ construction } & Construction cost \\
\hline & & Installation cost \\
\hline & & Ancillary facility fee \\
\hline & & Utility fee \\
\hline & & Management fees \\
\hline & & Finance charges \\
\hline & & Tax cost \\
\hline \multirow{3}{*}{$\begin{array}{c}\text { Operatio } \\
\mathrm{n} \text { and } \\
\text { maintena } \\
\text { nce }\end{array}$} & \multirow{2}{*}{ Lease merchants } & Cost of sales \\
\hline & & Investment cost \\
\hline & $\begin{array}{l}\text { Operating } \\
\text { services }\end{array}$ & Property management expenses \\
\hline
\end{tabular}

\subsection{RBS risk identification}

\subsubsection{Risk identification in the project planning stage}

\subsubsection{Technical risk}

(1)Park project cost data risk

Real estate enterprises generally have their own cost database, and whether the cost data is perfect and accurate directly affects the decision makers' judgment.

(2)Feasibility report quality risk
The quality of the feasibility report affects the investment process and causes cost losses in the investment process.

(3)Industry positioning risk

The real estate enterprises decide the quality positioning of the industrial park, and the investment cost of different grades of industrial parks is different.

(4)Financing scheme risk

Mainly including the interest paid to banks.

\subsubsection{Management risk}

(1)Governments communicate and coordinate risks

If the communication between real estate enterprises and the government is not coordinated, the project may be delayed and the preliminary construction cost will be affected.

(2)Risk of examination and approval procedures

In China, the examination and approval procedures are generally more complicated, so there are some risks in the examination and approval process.

(3)surrounding economy understanding degree risk

If researchers do not know the surrounding economic conditions and the quality of the research report is not high, it will cause the decision-makers to make wrong judgments and affect the cost at the decision-making stage.

\subsubsection{Environmental risks}

(1) Park related policy risks

The changes of macro policies more or less affect the input costs of real estate enterprises in the construction of parks.

(2)Planning requirements risk

If the planning does not meet the requirements, it may be faced with the modification of the design scheme, resulting in the increase of the initial cost.

(3) Construction standard risk

The construction of the park in accordance with the relevant standards, familiar with the construction standards in related fields.

(4) Capital source risk

If the capital chain breaks in the construction, it will cause significant losses to the project.

\subsubsection{Risk identification in the construction and implementation stage}

\subsubsection{Technical risks}

\section{(1)Technical parameter risk}

The survey and design stage will determine the project material equipment, if the material equipment and other parameters appear wrong will cause the cost increase.

\section{(2)Design change risk}

There may be design errors or changes in the design phase, affecting the cost in the design process. 
(3) Risk of missing items in the list

Omissions in the compilation of bill of quantities will affect the adjustment of the amount of works in the construction stage and cause the increase of costs.

(4) Construction process design change risk

The adjustment of the work in the design stage in the construction stage will result in the increase of the overall cost in the later stage.

(5)Engineering optimization risk

There may be some differences between engineering design and construction. In the construction process, the optimization of design scheme can save the actual construction cost while ensuring the quality and safety.

6) Visa risks

How to strictly examine the content of the visa forms is an important part of cost management.

(7)Risk of claim

The contractor may claim for compensation during the construction of the project.

\subsubsection{Management risks}

(1)Risk of experience audit of bidders

If the bidders have no experience, many unnecessary construction costs may be increased.

(2) Contract management risk

Any changes in the construction process should be based on contract.

(3)Design management mode risk

When enterprises choose the appropriate management mode, they will promote the communication among all participants in the design process more effectively.

(4) Supplier risk

A good supply relationship directly affects the cost, quality and schedule.

(5) Contractor risk

The company should evaluate the economic ability and credit of the contractor, so as to ensure that every expenditure is reasonable.

6) Project construction management risk

All kinds of unexpected risks will be faced in the construction process.

(7) Terms of payment risk

We should choose the appropriate way of payment according to the actual construction situation.

(8) The management system is imperfect

Formulating reasonable organization and management scheme can improve work efficiency and perfect management system can greatly reduce project cost.

\subsubsection{Environmental risks}

(1)Manpower machine price rise risk

While the class clearly in the contract the risk exists in all the participants, but prices for real estate enterprises.

(2)Force majeure risk
Some natural disasters in the construction process caused by the extension of the construction period, such risks are mainly borne by real estate enterprises.

(3) Risk of policy changes in the construction process

Real estate enterprises should observe the changes of policies in real time.

\subsubsection{Risk identification in the operation and maintenance stage}

\subsubsection{Technical risks}

(1) Sales mode risk

Different sales schemes are adopted according to different enterprises to reduce various costs incurred in the sales process.

(2)Investment scheme risk

The quality of the investment attraction scheme directly determines the quality of the enterprise.

(3) Risk of after-sales service system

Good after-sales service will reduce the later operating costs.

(4) Degree of intelligence risk

Intelligent automation can reduce labor input, thus reducing labor costs.

\subsubsection{Management risks}

(1)Risk of professional ability of sales team

The sales team need know the relevant regulations in the park, and give the biggest preferences to the enterprises within the acceptable scope, so as to bring the biggest benefits to the real estate developers.

(2) Investment team professional ability risk

The collection of information during the investment attraction process reflects the team's professional ability.

(3)Risk of comprehensive quality of personnel

Property management personnel should be strictly controlled, professional and technical ability of management personnel should be increased, and cost should be saved.

(4) Management mode lags behind the risk

More scientific methods should be introduced into the operation and maintenance management of the park.

\section{Establishment of risk evaluation index system}

\subsection{Screening of risk assessment indicators}

According to the results of risk factor analysis, the evaluation index system of the whole process cost of the industrial park was initially constructed, and then the index was screened by the questionnaire designed by the expert investigation method. The reliability and validity of the recovered questionnaires are tested to ensure the reasonableness and validity of the screening results of evaluation indicators. This questionnaire is mainly 
distributed to the management of real estate enterprises, the management of construction units, industrial park planning consulting units and university researchers. A total of 130 questionnaires were issued and 123 were recovered, with an effective rate of $94.6 \%$. The importance of each factor was divided into five grades: very important, relatively important, generally important, unimportant and extremely unimportant, with a score of $5,4,3,2$ and 1 respectively.

\subsubsection{Reliability test}

Kronbach coefficient is usually used for reliability test, and the correlation value is between the interval [0-1]. The higher the value, the better the verification reliability test effect and the higher the reliability; otherwise, the lower the reliability. Kronbach coefficient is calculated as follows:

$$
\alpha=\frac{\mathrm{k}}{\mathrm{k}+1}\left(1-\frac{\sum_{\mathrm{i}=1}^{\mathrm{k}} \sigma_{\mathrm{i}}^{2}}{\sigma^{2}}\right)
$$

Among them $\mathrm{k}$ is the number of factors, $\sigma_{i}^{2}$ is the ith factor score internal variance, $\sigma^{2}$ is the score variance of all factors.

The reliability test results of Kronbaha coefficient below 0.7 indicate that the questionnaire reliability test is unqualified. [0.7-0.8] indicates that variables need to be modified and adjusted; [0.8-0.9] indicates that the overall reliability of the questionnaire is relatively high, and the reliability test is qualified. In this paper, SPSS was used to test the reliability of the questionnaire, and $\alpha=0.869$ was obtained. The reliability test indicated that the variables in the questionnaire were reliable.

\subsubsection{Validity test}

In combination with the questionnaire on risk factors, this paper selects content validity (CVR) test to measure whether the selected index can accurately represent the whole-process cost risk of the high-tech industrial park. The value range of content validity CVR is between [$1,1]$, and the calculation formula is as follows:

$$
\mathrm{CVR}=\frac{\mathrm{n}_{\mathrm{a}}-\frac{\mathrm{n}}{2}}{\frac{\mathrm{n}}{2}}=\frac{2 \mathrm{n}_{\mathrm{a}}}{\mathrm{n}}-1
$$

Among them $\mathrm{n}$ is the number of effective survey experts, $\mathrm{n}_{\mathrm{a}}$ is the number of effective survey experts who believe that an indicator can well reflect the survey results (the number of experts with scores $\geq 3$ was selected in this paper).

In this paper, the critical value of CVR is set as 0.6, and the factors with $C V R \geq 0.6$ are retained. The factors with $\mathrm{CVR}<0.6$ are excluded.

\subsection{Determination of evaluation indexes}

After the reliability and validity test of the questionnaire, the preliminarily established risk indexes are screened according to the critical value. Finally, the risk evaluation indexes are classified and summarized according to their attributes, and a cost risk evaluation index system for high-tech industrial parks with 8 firstlevel evaluation indexes and 37 second-level evaluation indexes is established. The specific risk classification is as follows (Table 2) :

Table 2: Whole-process cost risk evaluation index system of real estate enterprise park construction

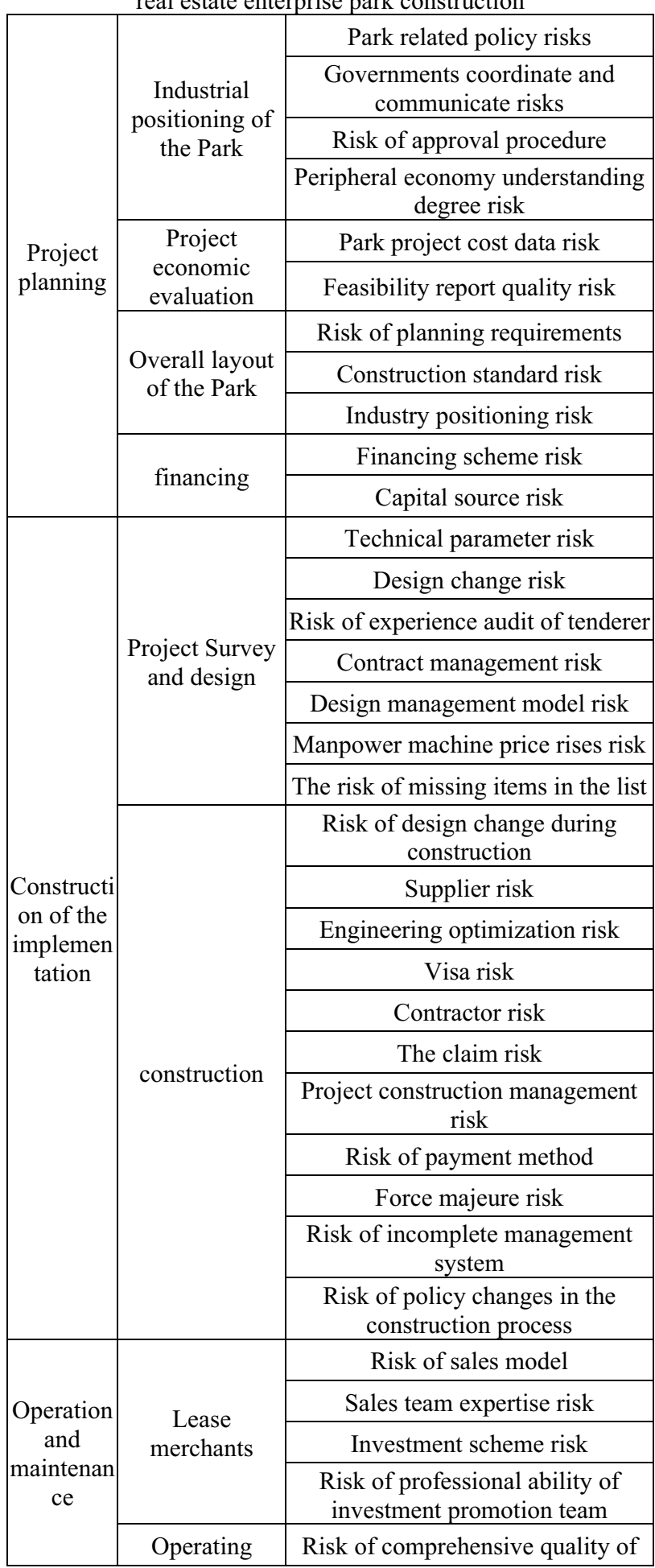




\begin{tabular}{|l|c|c|}
\hline \multirow{2}{*}{ services } & personnel \\
& & Management mode lag risk \\
& Risk of after-sales service system \\
& Intelligence level risk \\
\hline
\end{tabular}

\section{Application description of indicator system}

The establishment of evaluation index system is to pave the way for the follow-up risk evaluation and risk early warning. In the actual industrial park case, this index system is used to evaluate the overall risk of the project, score the overall cost risk of the project, and determine the risk interval of the project according to the size of the score for risk early warning. Risk assessment process on the basis of the evaluation index system, a quantitative or qualitative methods can be used to determine evaluation index weights risk, respectively evaluation index according to the weight of evaluation indexes for primary and secondary size to prioritize, whole process of industrial park cost impact of different factors, different factors influencing the degree of risk control of different ways. The risk management personnel in a timely manner to take corresponding measures to control risks, improve the overall industrial park project cost risk management level.

\section{Conclusion}

Through the analysis of real estate enterprise transformation industrial park, this paper finds that the original cost risk evaluation index system is not fully applicable to the park project. Then combined with the literature survey and expert interview, according to the characteristics of industrial park construction using WBS - CBS - RBS risk breakdown structure of industrial park construction whole process cost risk factors were analyzed. After induction in the form of questionnaire investigation, the result of the recovery of the questionnaire through the reliability and validity test, eight level is obtained by testing under the risk evaluation index and index of corresponding class of 37 secondary indexes, eventually forming industrial park construction cost of the whole process of risk evaluation index system. In the end, the application of the evaluation index system is explained, hoping to provide help for the follow-up cost risk evaluation and early warning research of the whole process of industrial park construction.

\section{References}

1. Yu, W. Y. (2019) The Profit Mode of China's Industrial Real Estate and its Future Development Trend, Technology and Finance, 10: 57-61.

2. Wang, Q. (2020) Research on Cost Control of Construction Project Based on Process Management, Building Economy, 41: 52-56.
3. Kong, L. Z., Zhang, Y. N., Yang, J., Zhang, X. J. (2016) Project Cost Risk Evaluation Based on Set Pair Analysis Method, Journal of Civil Engineering and Management, 33: 90-96.

4. Chen, Z. D. , Zou, Q. L. (2015) Cost Risk Analysis and Evaluation of Hydropower EPC Project Based on Entropy Weight, Water Resources and Power, 33: 168-171.

5. Zhou, L. T., Yuan, Z. M., Xu, C. H. , Tang, X. Y. (2019) Research on Cost Risk Management of Water Conservancy Project Based on Improved Cloud Model, Water Resources and Power, 37: 152$154+196$. 